DC 372.881.111.1

\title{
TEACHING EFL TO MIXED-ABILITY CLASSES: STRATEGIES, CHALLENGES, SOLUTIONS
}

\author{
N. M. Hordiienko, L. V. Lomakina \\ Kyiv, National Technical University of Ukraine \\ "Kyiv Polytechnic Institute" \\ eng12009@rambler.ru, 1lv270707@gmail.com
}

This article deals with the challenges English language teachers regularly face when working with so-called mixed-ability classes. The analysis of the main strategies presented by leading local and foreign scientists concerning the problem of teaching to different-level students in technical higher educational establishments is carried out. The article focuses on the importance of the problem mentioned as well as probable reasons of the prevalence of the problem. Taking into consideration the deficiency of system development of methods and approaches to teaching English in mixed-ability classes, the following scientific research is focused on scrutinising all sorts of possible solutions of the problem arising from the necessity to teach English in mixed-ability groups. The attempt to investigate strategies and methods that can be successfully applied in the process of English language teaching in mixed-ability groups was undertaken. The role of peer tutoring as one of the feasible solution of the problem is examined. The vital importance of facilitating favourable friendly atmosphere in the mixed-ability class is highlighted. The necessity to develop assignments of different levels of complexity presenting challenge for advanced students and not frustrating and demotivating the average ones is mentioned. Students' psychological problems arising in the process of learning a foreign language in different-level groups, particularly, in the process of improving communication skills, are considered. The article is of great help to all foreign language teachers interested in effective implementation of modern techniques and approaches that can have a positive impact on the teaching process in mixed-ability classes.

Key words: mixed-ability classes, higher educational establishment, peer tutoring, differentiation principle, psychological barrier, self-esteem.

Introduction. There is no need to say that at present multilingualism is an integral part of European community and the necessity to master several foreign languages underlies not only economic factors, but also overall political and cultural development of the individual. In this regard, nowadays it is quite obvious that teaching English as a foreign language in higher educational establishments is becoming increasingly important. Ukraine's integration into the world community and the establishment of closer economic, political and cultural ties has resulted in a dramatic increase of the necessity to master at least one foreign language. Higher educational establishments all over Ukraine actively participate in the process of Europeanization of higher education by shifting priority areas to including English to the curriculum at all stages of specialist education.

Background. There seems to be no compelling reason to argue that, unfortunately, English language teachers in technical higher educational establishments in the overwhelming majority of cases have to deal with so-called mixed-ability groups, where different students have different abilities and different level of language skills. This pressing problem, which almost all English teachers have to face regularly, is generally considered to be the biggest and should be given due consideration. Actually, the prevalence of the problem mentioned can be easily explained by the fact that rural school leavers come short of the English language 
knowledge compared to city school leavers. Moreover, even among students enrolled on a technical course there is certain amount of those having humanitarian mindset, which means that initially they have a head start on language skills compared to mechanical intelligence students. It is certain that this fact poses a significant challenge to the English language teacher. Despite the importance of the problem mentioned above, the analysis of native scientific and methodological literature has shown that there is a lack of scientific works devoted to investigation of strategies and methods that can be successfully applied in the process of English language teaching in mixed-ability groups.

Aim. Taking into consideration the deficiency of system development of methods and approaches to teaching English in mixed-ability classes, the following scientific research is focused on scrutinising all sorts of possible solutions of the problem arising from the necessity to teach English in mixed-ability groups. It seems fair to suggest that this issue is of top priority not only for technical higher educational establishment teachers. Nowadays, the problem is getting very common for all kinds of educational establishments as students tend to come from different learning backgrounds, they may differ significantly in the speed of acquiring knowledge, motivation, learning styles etc [2, p.48].

Usage of group's mixed abilities to teacher's advantage. Teachers can show their talent and professionalism by turning disadvantages into an asset during the class work. Surely, the work in different-level classes can be quite intimidating and challenging for young and inexperienced teachers, though the most appropriate and adequate solution to the problem is to be found. While teaching to mixed-ability groups it is essential to be aware of teaching strategies that can contribute to tackling the problem effectively. The problem appears to have a lot of negative aspects that still can be turned into positive ones. [3, p.2] Obviously, the teacher has to meet the needs of all the students of the class, thus in the process of acquiring knowledge it is crucial to organise the pair work in such a way that students start learning from each other.

Peer tutoring as one of the feasible solutions of the problem. It would be appropriate to quote French essayist Joseph Joubert who wrote: "To teach is to learn twice". It means that advanced learners will facilitate the development of average learners' skills while benefiting from it too. Bearing in mind the previous arguments we come to an unmistakable conclusion that peer tutoring can be a perfect solution to the problem of teaching in mixed-ability classes. The data yielded by this study provides convincing evidence that the use of pair work based on the principles of peer tutoring helped improve the skills of average learners while solidifying skills of advanced learners that were proud to fulfill the role of an "aide". Adopting a peerassisted learning strategy in different-level English classes the teacher assumes responsibility for putting students in pairs or small groups ensuring that advanced learners are put together with "underachievers". The proper choice of pairs for application of peer tutoring strategy results in the groundbreaking increase of students' motivation and achievements.

Hence, we come to a conclusion that peer tutoring can help not only in educational process enhancement, but also in facilitating favourable and homely atmosphere in the class. The scientific literature on the problems of peer tutoring abounds with examples of successful peer tutoring application in the system of higher 
education. Investigations and surveys into achievements and progress in developing all types of language skills indicate that average students tend to give positive evaluation of peer-assisted learning experience. [5] However, the teacher has to constantly keep an eye on the psychological atmosphere predominating among the students in mixed-ability classes as the chances of developing superiority complexes (advanced learners may be prone to it) and feeling of inferiority (inherent to weak students) are rather high in such groups.

The differentiation principle in assignments' complexity. Another possible solution to the problem of mixed-ability group teaching can be the development of assignments of different levels of complexity. [1, p.177] By "tuning" the complexity of the task, the English language teacher can be definitely sure that both average and advanced learners can cope successfully with the tasks as the level of complexity corresponds that of the knowledge of both groups of students, thereby presenting challenge for advanced students and not frustrating and demotivating the average ones. Thus, in mixed-ability groups English teachers have to tend to individualising and personalising of students' work. More complicated and challenging tasks assigned for advanced learners will definitely guarantee that they keep motivated and go on to make progress. It should be mentioned that this approach turned out to be successfully implemented in the teaching process, though it requires a lot of preparatory work.

The pace appropriateness in mixed-ability classes. It should be stressed that the problem of different levels of language skills and abilities to progress in acquiring foreign language knowledge among students of mixed-ability groups by no means isn't to be ignored by English language teachers. The circumstances mentioned should be paid close and careful attention to while choosing proper and convenient pace of the lesson in general or definite task in particular. It would be reasonable to adhere to the principles of mindful evaluation of the adjustments and constant finetuning of the lesson's pace. Otherwise, we may come to the point where advanced students may become bored and demotivated by the slow pace of the lesson or weak students can get frustrated by their inability to keep up with the advanced students' pace. The occurrence of the situation described is totally unacceptable and should be avoided in every imaginable way since it is much easier to prevent the development of this unfavourable and inexcusable scenario than to deal with the consequences that sometimes, unfortunately, can become irreversible.

Typical problems associated with teaching to mixed-ability classes. The teacher of a mixed-ability class should be aware of typical problems arising in the mixed-ability groups and possible ways to solve them. One of the common problem to be solved revolves around the high probability of developing inferiority complexes leading to demotivation of average students. Our observations have proved that the main factor affecting the participation in speaking activity within a given communicative situation is neither the absence of the necessary basic knowledge on the subject (so-called lexical and grammatical minimum), nor a lack of a wish to carry on a conversation on a given topic, because of insufficient understanding of the subject, but the presence of psychological barrier not allowing to overcome different types of fears, e.g. the fear of making a mistake, the fear of a new activity in the presence of an audience and unwillingness to be subjected to critical evaluation by the teacher or other students. 
Bearing in mind all the factors mentioned above, the task of the English language teacher of the different-level group resolves itself thereby to giving equal attention to both advanced and average students. It is quite clear that the former tends to participate more actively during the lesson, whereas the latter feels embarrassment and prefers to maintain silence. In this case, lack of due attention from the teacher or immanent restraint in communication activities may negatively affect underachievers' progress in acquiring language skills. It is important to remember that there is no use trying to force average students lacking speaking skills to talk, thereby provoking possible aggravation of the fear to make mistake and making them even less reluctant to speak in the future. It would be sensible to create amicable learning environment in the mixed-ability group, where learners are not afraid of making mistakes and being ridiculed.

Naturally, not all students are affected by the above mentioned factors. Basically, it is common for people with low self-esteem and high levels of anxiety, i.e. people experiencing psychological distress in all situations associated with the evaluation of their activities. [4] Since learning a foreign language is associated with a large number of errors (that is surely inevitable when learning new skills), participation in speaking activities becomes a major stress for students who are seeking to meet the expectations of others and are afraid to fail (i.e. to make a mistake speaking foreign language), which is a consequence of low self-esteem and self-doubt.

Unfortunately, these psychological characteristics are inherent to a large number of students, which means that the main task of the lesson will not be accomplished and such students will not acquire communication skills, learn to use a foreign language for its intended purpose, i.e. as a means of communication. Taking into consideration all the above mentioned factors, it is important to help the teacher find the necessary solutions so that the educational process might be carried out to the full extent, while minimizing stress factors arising in the process of foreign language communication.

Conclusions. The research conducted doesn't encompass the comprehensive solution of all problems, the English language teachers face, working with different-level students in technical higher educational establishments. At the same time, its results definitely indicate that in spite of the fact that the problem of teaching to mixed-ability group tends to become ubiquitous and is one of the biggest and, we dare say, the most challenging teaching problems, it can still be successfully solved by applying strategies described above. The English language teacher dealing with a mixed-ability class has to adopt a mixture of solutions meeting the needs of both advanced and average students, simultaneously facilitating favourable and friendly atmosphere among all members of the academic group. The golden mean in treating advanced and average learners is to be found behaving in supportive and encouraging way to create successful teaching and learning environment. The outcomes of the following scientific and practical research can be used to identify the perspective directions of studying this problem in the future. It would be appropriate to carry out in-depth analysis of psychological factors affecting the efficiency of students' progressing in acquiring language skills in different-level English classes, the questions of the application of the newest technologies in the process of teaching to mixed-ability classes that, supposedly, can be extremely helpful in solving the problem discussed require further development. Further research in this area may include the role of self-study facilities equipped with the cutting-edge appliances allowing English language teachers to concentrate on advanced learner groups and average learner groups alternately. 


\section{REFERENCES}

1. Harmer, J. (2007). How to Teach English. Essex: Pearson Longman.

2. Harmer, J. (2001). The practice of English language teaching. Harlow: Longman.

3. Hess, N. (2001).Teaching Large Multilevel Classes. Cambridge: Cambridge University Press.

4. Phillips, E. (1991). Anxiety and Oral Competence: Classroom Dilemma. The French Review, 65, 1-14.

5. Topping, K. (1996). The Effectiveness of Peer Tutoring in Further and Higher Education: A Typology and Review. Higher Education, 32, 321-345

Н. М. Гордієнко, Л. В. Ломакіна. Викладання англійської мови як іноземної в неоднорідних групах: стратегії, проблеми, рішення.

Дана стаття присвячена розгляду актуальної проблеми, з якою регулярно стикаються вчителі англійської мови при викладанні у так званих змішаних або неоднорідних групах. Запропонований аналіз основних стратегій викладання студентам неоднорідних груп в технічних вищих навчальних закладах. У статті зосереджена увага на важливості згаданої проблеми, а також ймовірних причинах ii поширеності. Беручи до уваги недостатній розвиток системних методів і підходів до навчання англійської мови у неоднорідних групах, дане наукове дослідження зосереджене на опрацюванні всіх видів можливих рішень проблеми, пов'язаної з необхідністю викладати англійську мову подібним групам. Була зроблена спроба дослідити стратегії і методи, які можуть бути успішно застосовані в процесі викладання англійської мови в змішаних групах. Була досліджена роль такого метода як "peer tutoring" в якості одного $з$ допустимого вирішення проблеми. У статті підкреслюється надзвичайно важливе значення докладанню зусиль задля створення сприятливої дружньої атмосфери в класах змішаних здібностей. Підкреслена необхідність розробки завдань різних рівнів складності, що представляють своєрідний виклик для просунутих студентів і не демотивують слабких студентів. Були розглянуті психологічні проблеми студентів, що виникають у процесі вивчення іноземної мови в групах різного рівня, зокрема, в процесі вдосконалення навичок спілкування. Стаття $є$ великою підмогою для всіх вчителів іноземної мови, зацікавлених в ефективній реалізації сучасних методів і підходів, які можуть позитивно вплинути на навчальний процес у неоднорідних групах.

Ключові слова: неоднорідні групи, вищий навчальний заклад, психологічний бар'єр, комплекс неповноцінності, принцип диференціації.

Н.Н. Гордиенко, Л.В. Ломакина. Преподавание английского языка как иностранного в неоднородных группах: стратегии, проблемы, решения.

Данная статья посвящена актуальной в настоящее время проблеме преподавания английского языка в смешанных группах. Проведен анализ существующей отечественной и зарубежной научно-методической литературы, посвященной вышеуказанной проблеме. В статье сосредоточено внимание на важности данной проблемы, а также вероятных причинах еe распространенности. Была предпринята попытка исследовать стратегии и методы, которые могут быть успешно применены в процессе преподавания английского языка в неоднородных группах. В статье подчеркивается чрезвычайно важное значение приложения усилий для создания благоприятной дружеской атмосферы в смешанных классах. Подчеркнута необходимость разработки заданий различных уровней сложности для сильных и слабых студентов. Были рассмотрены психологические проблемы студентов, которые возникают в процессе изучения иностранного языка в неоднородных группах, в частности, в процессе совершенствования навыков общения. Статья является большим подспорьем для всех преподавателей иностранного языка, заинтересованных в эффективной реализации современных методов и подходов, которые могут оказать положительное влияние на учебный процесс в подобных группах.

Ключевые слова: неоднородные группы, высшее учебное заведение, психологический барьер, комплекс неполноценности, принцип дифференциации. 